\title{
Effect of intramuscular injection of butafosfan and cobalamin on the quality of Fresh and Cooled Stallion Semen
}

\section{Efeito da administração intramuscular de butafosfan e cobalamina na qualidade do Sêmen Fresco e Resfriado de Garanhões}

\author{
Nicolás Cazales Penino ${ }^{1 *}$; Gabriel de Oliveira Santos²; Murilo Farias Rodrigues²; \\ Henrique Boll de Araujo Bastos ${ }^{2}$; Gustavo Henrique Zimmermann Winter'; \\ Ivan Cunha Bustamante-Filho²; Anita Mylius Pimentel²; \\ Ricardo Macedo Gregory ${ }^{3}$; Rodrigo Costa Mattos ${ }^{3}$
}

\begin{abstract}
The use of butafosfan in combination with cobalamin modulates many cellular metabolic functions in several species. Its use enhances productive and reproductive performance and reduces stress responses in animals. Despite all these attributes, so far there have been no controlled studies to evaluate the effects of butafosfan and cobalamin on the quality of stallion semen. The purpose of this study was to evaluate the action of butafosfan in combination with cobalamin on the quality of fresh and cooled stallion semen. Four healthy stallions were kept in the same place and under the same management conditions during the entire experiment. Stallions were randomly assigned to two treatment groups in a $2 \times 2$ crossover design. Group A stallions were treated with an intramuscular injection of butafosfan twice a week for 80 days, while group B did not receive any treatment. After that, both groups were not treated for another 80 days allowing a washout period for the treated group. Then, the groups were reversed, and group B was treated with butafosfan and group A acted as the control for another 80 days. Semen was collected twice a week, diluted in skim milk and evaluated for total sperm count, total and progressive sperm motility, membrane integrity (CFDA/PI staining) and membrane functionality (HOS test) at 0 and 24 hours after preservation at $5^{\circ} \mathrm{C}$. Data were analyzed by comparing the values obtained from the treated stallions between the $60^{\text {th }}$ and $84^{\text {th }}$ days of treatment and the values obtained from the same stallion during the control period. The ejaculates of the washout period and between days 1 and 63 of treatment were not considered. A total of 85 ejaculates were analyzed by one-way ANOVA. Means were compared by the Tukey test at the $5 \%$ level of significance. No significant differences were observed in fresh and cooled semen regarding the total sperm count, total motility, progressive motility, membrane integrity and membrane functionality in the treated and control groups respectively. No interactions were detected in the fresh and cooled semen. The use of butafosfan and cobalamin in the stallions did not affect the seminal quality of young and fertile stallions. It can be used routinely and safely in these stallions. However, contrary to observations in humans and in bulls, the use of cobalamin did not improve semen parameters in these stallions.
\end{abstract}

Key words: Equine, sperm, Catosal B12

1 Discente, REPROLAB, Laboratório de Reprodução Animal, PPGMA:Equinos. Faculdade de Veterinária, Universidade Federal do Rio Grande do Sul, UFRGS, Porto Alegre, RS, Brasil. Bolsista CAPES/UDELAR, Universidad de la Republica, Montevideo. E-mail: nicolascazales@hotmail.com

2 Discentes, REPROLAB, Laboratório de Reprodução Animal, PPGMA: Equinos. Faculdade de Veterinária, UFRGS, Porto Alegre, RS, Brasil.E-mail: gabrieldoliveira@hotmail.com; murilofarias@icloud.com; henriquebastosvet@gmail.com; gustavo@ personalhorse.com.br; anitapimentel@gmail.com; ivanbustamante@univates.br

3 Profs., REPROLAB - Laboratório de Reprodução Animal, PPGMA: Equinos. Faculdade de Veterinária, UFRGS, Porto Alegre, RS, Brasil. E-mail: ricardo.gregory@ufrgs.br; rcmattos@ufrgs.br

* Author for correspondence 


\section{Resumo}

A utilização de Butafosfan em combinação com cobalamina modula uma série de funções metabólicas celulares em várias espécies. Seu uso melhora o desempenho produtivo e reprodutivo e reduz as respostas ao estresse em animais. Apesar de todos esses atributos, até agora não houve estudos controlados para avaliar os efeitos da substância Butafosfan e cobalamina sobre a qualidade do sêmen de garanhões. O objetivo deste estudo foi avaliar a ação do Butafosfan em combinação com cobalamina sobre a qualidade do sêmen fresco e resfriado de garanhões. Quatro garanhões saudáveis foram mantidos no mesmo lugar e sob as mesmas condições de manejo durante todo o experimento. Garanhões foram divididos aleatoriamente em dois grupos de tratamento em um desenho cruzado 2x2. Garanhões do grupo A foram tratados com uma injeção intramuscular de Butafosfan duas vezes por semana durante 80 dias, enquanto o grupo B não recebeu qualquer tratamento. Depois disso, ambos os grupos não foram tratados durante mais 80 dias, permitindo um período de washout para o grupo tratado. Em seguida, os grupos foram invertidos, o grupo B foi tratado com Butafosfan enquanto o grupo A agiu como controle por mais 80 dias. $\mathrm{O}$ sêmen foi coletado duas vezes por semana, diluído em leite desnatado e avaliado para a contagem total de espermatozoides, motilidade progressiva e total, integridade da membrana (coloração CFDA/PI) e funcionalidade de membrana (teste HOS) em 0 e 24 horas após conservação a $5^{\circ} \mathrm{C}$. Os dados foram analisados comparando os valores obtidos a partir dos garanhões tratados entre os dias 60 e 84 de tratamento e os valores obtidos a partir do mesmo garanhão durante o período de controle. Não foram considerados os ejaculados do período washout entre os dias 1 e 63 de tratamento. Um total de 85 ejaculados foram analisados por análise de variância simples (ANOVA). As médias foram comparadas pelo teste de Tukey ao nível de 5\% de significância. Nenhuma diferença significativa foi observada no sêmen fresco e refrigerado em relação à contagem total de espermatozoides, motilidade total, motilidade progressiva, integridade de membrana e funcionalidade de membrana, nos grupos tratados e controle, respectivamente. Não foram detectadas interações no sêmen fresco e resfriado. O uso de Butafosfan e cobalamina não afetou a qualidade seminal de garanhões jovens e férteis. Ele pode ser usado rotineiramente e com segurança em garanhões. No entanto, contrariamente às observações em humanos e touros, o uso de cobalamina não melhorou os parâmetros seminais nestes garanhões.

Palavras-chave: Equino, sêmen, Catosal B12

\section{Introduction}

Nutrition is an important cause of subfertility, but has been poorly studied in the diagnostic and treatment of the reproductive disorders. In recent years, interest has increased in the role of $B$ vitamins as modulators of fertility outcomes as they are essential in spermatogenesis (BOXMEER et al., 2009). During spermatogenesis, most of the cytoplasm of the spermatozoa is discarded, through which the availability of nutrients and defensive cytosolic enzymes is limited. This may result in higher sensitivity to DNA damage (BOXMEER et al., 2009; EBISCH et al., 2006). Deficient B vitamin concentrations cause elevated homocysteine concentrations and impair the remethylation cycle. This metabolism is involved in the methylation of phospholipids, proteins, DNA, and RNA and in the synthesis and repair of DNA. These processes are essential in spermatogenesis; therefore, derangements in this pathway may be detrimental to reproduction. Because DNA synthesis is a main part of spermatogenesis, B vitamins are probably important in this process, and functional deficiencies are a risk factor for male subfertility (AL-MASKARI et al., 2012; BOXMEER et al., 2009; WONG et al., 2002).

The use of butafosfan, a phosphoric acid compound, in combination with cobalamin, modulates many cellular metabolic functions in several species. Its use enhances the productive and reproductive performance and reduces stress responses in animals. Despite these attributes, so far there are no controlled studies that have evaluated the effects of butafosfan and cobalamin on seminal quality in stallions (DENIZ et al., 2009; LOPES et al., 2010; PEREIRA et al., 2012; ROLLIN et al., 
2010). The purpose of this study was to evaluate the action of butafosfan, in combination with cobalamin, on the quality of fresh and cooled stallion semen.

\section{Material and Methods}

\section{Animals}

Four Thoroughbred stallions were used, with ages ranging between 6 and 15 years, weighing on average $500 \mathrm{~kg}$ (470-525), with body condition $>4$ (MALSCHITZKY et al., 2001) and proven normal fertility. Stallions were maintained under similar handling and feeding conditions during the trial. These stallions were part of an experimental herd and were maintained isolated in an open field, supplemented twice a day with oats and alfalfa hay, with ad libitum access to water and minerals.

\section{Experimental design}

Stallions were submitted to a washout period. Semen was collected once a day for five days to eliminate spermatic extragonadal reserves. After the washout period, semen was collected from the stallions twice a week during the 336 days of the experiment. The stallions were randomly assigned to two groups, A and B, each with two sires. One group was the treatment group and the other was the control group. Catosal B12 ${ }^{\circledR}$, containing $5000 \mu \mathrm{g}$ of cyanocobalamin and $10 \mathrm{~g}$ of butafosfan, which is equivalent to $17.3 \mathrm{mg}$ of organic phosphorus in the form of [1-(n-butyl-amino)-1-methylethyl]phosphoric acid (100 $\mathrm{mL}$ each), was used as the treatment. A $25 \mathrm{~mL}$ IM dose of Catosal B12® was employed in this study following the manufacturer's recommendations, calculated for a $500 \mathrm{~kg}$ stallion at $5 \mathrm{~mL} / 100 \mathrm{~kg}$ and administrated twice a week on the same day as semen collection. The experiment was divided into four periods of 84 days each.

During the first period, group A was treated with Catosal B $12^{\circledR}$ and group B was not treated, serving as the control. After that, both groups were not treated for another 84 days to provide a washout period for the treated group. Then, the groups were reversed, and group B was treated with butafosfan and group A acted as the control for another 84 days. Finally, in the fourth period, no group was submitted to any treatment (Fig 1).

\section{Experimental procedures}

Ejaculates were collected twice a week using an artificial vagina (Hannover model, Minitube $\mathrm{GmbH}$, Germany) (GÖTZE, 1949) using an estrous mare during the experimental period (KLUG, 1982). After collection, the gel fraction was removed and the semen was filtered through sterile gauze. Semen examinations were performed immediately after collection. Free gel volume was directly measured with the use of a test tube, the concentration was determined and the total sperm count was calculated. Semen was diluted with skim milk (MEIRELLES et al., 1998) to a final concentration of 25 million sperm/mL (SAMPER, 2000). Total and progressive motility, as well as plasma membrane integrity and functionality were estimated (LAGARES et al., 2000). Sperm morphology was evaluated using a light microscope (1000x) by counting 200 cells from each collected ejaculate, in a semen smear stained with Cerovsky (MATTOS et al., 1990). Cells were classified as normal or those with primary and secondary abnormalities. Semen was cooled at $5^{\circ} \mathrm{C}$ for $24 \mathrm{~h}$ and evaluated again regarding total and progressive motility and plasma membrane integrity and functionality.

\section{Plasma membrane integrity}

Plasma membrane integrity was evaluated using fluorescent probes. An aliquot of $950 \mu \mathrm{L}$ of semen was treated with $20 \mu \mathrm{L}$ of formol-citrate and $10 \mu \mathrm{L}$ of a propidium iodide (PI) solution $(0.5$ $\mathrm{mg}$ PI in $1 \mathrm{~mL} 0.9 \% \mathrm{NaCl}$ solution) and $20 \mu \mathrm{L}$ of carboxyfluorescein diacetate (CFDA) solution (0.46 mg CFDA in $1 \mathrm{~mL}$ DMSO) and incubated for 
8 minutes at $30^{\circ} \mathrm{C}$. Samples were analyzed using a fluorescence microscope. A total of 200 cells were counted. Sperm stained totally green were considered to be cells with good plasma membrane integrity. Cells stained red were considered to be damaged sperm (KNEISSL, 1993).

\section{Plasma membrane functionality}

The hypoosmotic swelling test (HOST) was performed by adding $100 \mu \mathrm{L}$ of semen to $200 \mu \mathrm{L}$ of distilled water and incubating the sample for 8 minutes in a water bath at $37^{\circ} \mathrm{C}$. Using phase contrast microscopy (400x), two experienced technicians assessed the HOST response in 200 cells; the mean of both counts was used. The response was classified into two categories: (1) sperm with coiled/curled tails were considered sperm with functional integrity of the plasma membrane (2) sperm with straight tails were considered sperm without functional integrity of the plasma membrane (LAGARES et al., 1998).

\section{Statistical analysis}

A $2 \times 2$ crossover design was proposed, where four stallions were divided randomly into two groups. To evaluate the effect of Catosal B12 ${ }^{\circledR}$ treatment, the semen data were analyzed by a one-way ANOVA, comparing the values obtained from animals treated between the $60^{\text {th }}$ and the $84^{\text {th }}$ days of treatment and the values of the same stallions during the control periods (Figure 1). The ejaculates obtained during the washout period (Figure 1) and between the $1^{\text {st }}$ and $59^{\text {th }}$ days of the treatment periods were not used. A total of 85 ejaculates were analyzed. ANOVA was performed, adopting a model of subdivided parcels with periods of treatment and controls. The stallions were considered as the main variables and total and progressive motility, concentration, total sperm count, plasma membrane integrity and functionality and sperm morphology were considered as the dependent variables. The Tukey test was used to compare means when a significant effect was obtained. A probability of $\mathrm{P} \leq 0.05$ indicated that a difference was significant.

Figure 1. Graphical layout of the five stages of treatment: PSD - period of sperm depletion; DC - daily semen collections; ST 1 - Stage 1 (group A treatment); ST 2 - Stage 2 (discard period of group A); ST 3 - Stage 3 (group B treatment); ST 4 - Stage 4 (discard period of group B).

\begin{tabular}{|c|c|c|c|c|c|}
\hline GROUP & $\begin{array}{c}\text { PSD } \\
\text { (5 days) }\end{array}$ & $\begin{array}{c}\text { ST 1 } \\
\text { (84 days) }\end{array}$ & $\begin{array}{c}\text { ST 2 } \\
\text { (84 days) }\end{array}$ & $\begin{array}{c}\text { ST 3 } \\
\text { (84 days) }\end{array}$ & $\begin{array}{c}\text { ST 4 } \\
\text { (84 days })\end{array}$ \\
\hline A (n=2) & DC & Treatment & Discard & Control & Control \\
\hline B (n=2) & DC & Control & Control & Treatment & Discard \\
\hline
\end{tabular}

\section{Results}

In the present experiment, a total of 368 semen collections were performed on four stallions. No differences were detected among the treated and the control groups for the different variables analyzed in the fresh diluted semen (Table 1) or in the cooled semen stored for $24 \mathrm{~h}$ at $4^{\circ} \mathrm{C}$ (Table 2). No interactions were detected between sperm parameters and stallions. 
Table 1. Mean values, standard deviation and $P$ values of fresh semen during the final 24 days of the treatment period (TP) and control $(\mathrm{CN})$.

\begin{tabular}{lccc}
\hline & TP & CN & $P$ \\
\hline Volume (mL) & $37.2 \pm 14.3$ & $39.2 \pm 18.4$ & 0.62 \\
Concentration (x10 $\mathrm{spz} / \mathrm{mL})$ & $156.5 \pm 72.7$ & $160.6 \pm 80.8$ & 0.82 \\
TSN (x10 $\left.0^{9} \mathrm{spz}\right)$ & $5.25 \pm 2.4$ & $6.01 \pm 3.4$ & 0.29 \\
Total motility (\%) & $75 \pm 15$ & $71 \pm 12$ & 0.22 \\
Progressive motility (\%) & $54 \pm 17$ & $51 \pm 16$ & 0.43 \\
Plasma membrane function (HOST, \%) & $68.6 \pm 13.3$ & $67.4 \pm 12.7$ & 0.71 \\
Plasma membrane integrity (CFDA/PI, \%) & $71.2 \pm 13.6$ & $70.7 \pm 10.7$ & 0.84 \\
Normal sperm (\%) & $58 \pm 15$ & $54 \pm 12$ & 0.22 \\
\hline
\end{tabular}

(TSN - total sperm number).

Table 2. Mean values, standard deviation and $P$ values of semen cooled for 24 hours at $+5^{\circ} \mathrm{C}$ in the final 24 days of the treatment period (TP) and control $(\mathrm{CN})$.

\begin{tabular}{lccc}
\hline & TP & CN & $P$ \\
\hline Total motility (\%) & $54 \pm 21$ & $49 \pm 18$ & 0.27 \\
Progressive motility (\%) & $38 \pm 18$ & $32 \pm 16$ & 0.14 \\
Plasma membrane function (HOST, \%) & $49 \pm 16$ & $50 \pm 15$ & 0.62 \\
Plasma membrane integrity (CFDA/PI, \%) & $60 \pm 16$ & $58 \pm 15$ & 0.63 \\
\hline
\end{tabular}

\section{Discussion}

Catosal $\mathrm{B} 12^{\circledR}$ is an organic metabolic stimulant and tonic for use in a wide variety of species. The prolonged use of Catosal B12® is not known to affect spermatogenesis and male fertility. Studies in different species have shown the importance of cobalamin on spermatogenesis and its positive effects on seminal quality; however, no studies have been performed in stallions (BLAIR et al., 1968; BOXMEER et al., 2009; FURNASS, 1963; SCHMID et al., 2012; WATSON, 1962; WONG et al., 2002).

This study shows that prolonged use of butafosfan and cobalamin does not alter the seminal quality of young, fertile stallions. Butafosfan and cobalamin can be used safely in stallions because they did not elicit adverse effects on seminal parameters.

In this study, we tested the hypothesis that the synergistic action of butafosfan and cyanocobalamin participate actively in metabolic and physiological events as well as cell proliferation. These elements are important in the processes of energy release and in the structural stability of nucleic acids and cell membranes. Both cobalamin and organic phosphorus reduce the negative effects of glucocorticoids in response to stress factors and improve cell proliferation and the circulatory system. Therefore, a source of organic phosphorus and cobalamin as a supplement to increase its availability in the body could improve spermatogenesis and seminal quality in subfertile or senile stallions.

The intramuscular administration of cobalamin is effective not only in the correction of anemia, but it also improves the maturation and motility of human sperm (SHARP; WITTS, 1962). On the other hand, the addition of cobalamin to stored bull semen improved sperm motility and increased the level of fertility (BUSCH, 1957). Low levels of cobalamin in semen can be detected several months before anemia, and vitamin deficiency may be responsible for human infertility (ADAMS, 1958). The administration of intramuscular injections of cobalamin for seven months improved the semen 
of two men with poor quality semen, probably due to heavy smoking and alcohol consumption (BLAIR et al., 1968). These cases confirm other studies evaluating the influence of cobalamin on the fertility of mammals, suggesting that cobalamin may be beneficial in the treatment of poor fertility in males (BLAIR et al., 1968; SCHMID et al., 2012).

The results of this study demonstrate that IM administration of $25 \mathrm{~mL}$ Catosal B12® $(1250 \mu \mathrm{g}$ of cyanocobalamin and $2.5 \mathrm{~g}$ of butafosfan), twice a week for 84 days, did not modify any of the seminal parameters evaluated. This contrasts with results obtained in other species, in which the use of cobalamin improved seminal parameters in humans and in bulls (BLAIR et al., 1968; BOXMEER et al., 2009; FURNASS, 1963; SCHMID et al., 2012; WATSON, 1962; WONG et al., 2002). This, perhaps, is due to the fact that the stallions used in this study were young, fertile stallions, with good semen quality. Moreover, in the present study, we used only the combination of cobalamin with butafosfan, unlike the supplements in other experiments, where in addition to cobalamin, vitamin B9 (folate), zinc and other vitamins and antioxidants were used. Folate, zinc and cobalamin act synergistically in some metabolic pathways, potentiating the effect (AL-MASKARI et al., 2012). Animal studies in vitro and in vivo have shown that zinc deficiency alters the absorption and metabolism of folate and cobalamin in the diet and that a lack of cobalamin reduces the availability of folate in the body (FAVIER, 1992). In addition to folate, cobalamin and zinc are essential for the synthesis of RNA and DNA. However, the mechanisms involved in the effect of micronutrients on spermatogenesis are not yet clear (WONG et al., 2002).

In the present work, the dose of cyanocobalamin used and recommended by the manufacturer may have been why we did not observe an improvement in seminal quality in the treated stallions. The doses used were much smaller than those used and recommended for cattle (ROLLIN et al., 2010) and humans (FENECH, 2012; SOLOMON, 2007). The results based on a variety of biomarkers of DNA damage suggests that, at least, three times above the recommended dietary intake levels of cobalamin and folate are necessary to achieve adequate therapeutic concentrations of these vitamins in tissues in order to minimize damage to DNA (FENECH, 2012).

Cobalamin and butafosfan diminish the negative effects of glucocorticoids on spermatogenesis and sperm maturation (AURICH; AURICH, 2008; DENIZ et al., 2009). Both cobalamin and phosphorus participate in the function of enzymes that modulate the intracellular concentrations of glucocorticoids, maintaining a balance between the active and inactive forms, cortisone and cortisol respectively (GE et al., 2005; SHARP; WITTS, 1962). Therefore, butafosfan and cobalamin could have a protective effect on testicular function in stallions in stressful situations or on prolonged treatment with steroids. This effect was not observed in this experiment, probably because we used stallions with good seminal quality and housed in stress-free conditions.

Cobalamin has a systemic effect on improving the blood circulation and thus tissue oxygenation (COPPO; GAPEL, 2000; MARBACH, 1978, 1980; SOLOMON, 2007). Therefore, the use of butafosfan and cobalamin could be tested in the treatment of stallions with reproductive circulatory alterations like varicocele.

There are commercial products available containing cobalamin, folate, zinc, antioxidants, amino acids and minerals to treat reproductive problems in humans. Previous findings have emphasized the importance of these micronutrients on spermatogenesis and, unlike genetic factors, nutritional factors can be changed. So, parenteral or oral supplementation is a proven and useful tool for the treatment of male subfertility. However, the doses and micronutrients that have a greater impact on fertility in stallions leading to an increase in pregnancy rates are not yet fully elucidated (WONG et al., 2002). 
In future studies, it will be necessary to increase the dose of Catosal B12®, combining it with zinc and folate and using it on old stallions or stallions with fertility problems. The use of Catosal B12® intramuscularly had no negative effects and can be used routinely and safely in breeding stallions. Intramuscular treatment with butafosfan and cobalamin at the dose recommended by the manufacturer, for 84 days, did not alter fresh or cooled semen quality in young and fertile stallions. Other study with a larger number of animals and different doses is necessary to verify a possible beneficial effect on semen quality of the use of butafosfan and cobalamin in stallions.

\section{Conclusion}

The use of butafosfan and intramuscular cobalamin had no negative effects on the quality of fresh or chilled semen and can be used routinely and safely in young, fertile stallions.

\section{Sources and Manufacturers}

${ }^{1}$ Catosal B12 ${ }^{\circledR}$ (Bayer S.A., São Paulo, Brazil)

Funding. Financial assistance for this research was provided by CNPq.

Declaration of interest. The authors report no conflicts of interest. The authors alone are responsible for the content and writing of the paper.

\section{References}

ADAMS, J. F. Vitamin $B_{12}$ and fertility. Scottish Medical Journal, Glasgow, v. 3, n. 1, p. 21-25, 1958.

AL-MASKARI, M. Y.; WALY, M. I.; ALI, A.; ALSHUAIBI, Y. S.; OUHTIT, A. Folate and vitamin B12 deficiency and hyperhomocysteinemia promote oxidative stress in adult type 2 diabetes. Nutrition, Burbank, v. 28, n. 7-8, p. e23-e26, 2012.

AURICH, C.; AURICH, J. E. Effects of stress on reproductive function in the horse. Pferdeheilkunde, Baden-Baden, v. 24, n. 1, p. 99-102, 2008.
BLAIR, J. H.; STEARNS, H. E.; SIMPSON, G. M. Vitamin $\mathrm{B}_{12}$ and fertility. Lancet, London, v. 291, n. 7532, p. 49-50, 1968.

BOXMEER, J. C.; SMIT, M.; UTOMO, E.; ROMIJN, J. C.; EIJKEMANS, M. J.; LINDEMANS, J.; LAVEN, J. S.; MACKLON, N. S.; STEEGERS, E. A.; STEEGERSTHEUNISSEN, R. P. Low folate in seminal plasma is associated with increased sperm DNA damage. Fertility and Sterility, New York, v. 92, n. 2, p. 548-556, 2009.

BUSCH, E. Seminal vitamin $\mathrm{B}_{12}$ and sterility. Animal Breeding Abstracts, Wallingford, v. 25, p. 147, 1957.

COPPO, J. A.; GAPEL, E. R. Results from Catosal B12 applied on race horses in Argentina. A Hora Veterinária, Porto Alegre, v. 19, n. 113, p. 46-48, 2000.

DENIZ, A.; SPIECKER-HAUSER, U.; REHAGEN, M. Efficacy of a butafosfan and vitamin B12 combination (Catosal $\left.{ }^{\circledR}\right)$ on biochemical and hematological blood parameters in dogs treated with dexamethasone. International Journal of Applied Research in Veterinary Medicine, Apopka, v. 7, n. 3, p. 116-129, 2009.

EBISCH, I. M.; PETERS, W. H.; THOMAS, C. M.; WeTZELS, A. M.; PEER, P. G.; STEEGERSTHEUNISSEN, R. P. Homocysteine, glutathione and related thiols affect fertility parameters in the (sub)fertile couple. Human Reproduction Update, Oxford, v. 21, n. 7, p. 1725-1733, 2006.

FAVIER, A. E. The role of zinc in reproduction. Hormonal mechanisms. Biological Trace Element Research, London, v. 32, n. 1, p. 363-382, 1992.

FENECH, M. Folate (vitamin B9) and vitamin $B_{12}$ and their function in the maintenance of nuclear and mitochondrial genome integrity. Mutation Research, Amsterdam, v. 733, n. 1-2, p. 21-33, 2012.

FURNASS, S. B. Seminal vitamin $B_{12}$ and sterility. Lancet, London, v. 281, n. 7271, p. 59-60, 1963.

GE, R. S.; DONG, Q.; NIU, E. M.; SOTTAS, C. M.; HARDY, D. O.; CATTERALL, J. F.; LATIF, S. A.; MORRIS, D. J.; HARDY, M. P. 11beta-hydroxiesteroid dehydrogenase 2 in rat Leydig cells its role in blunting glucocorticoid action at physiological levels of substrate. Endocrinology, Los Angeles, v. 146, n. 6, p. 2657-2664, 2005 .

GÖTZE, R. Besamung und unfruchtbarkeit der haussäugetiere. Hannover: Scharper Verlag, 1949. 613 p.

KLUG, E. Untersuchungen zur klinischen andrologie des pferdes - die bedeutung andrologischer befunde am hengst für den zuchteinsatz. 1982. Tese (Livre Docência em Medicina Veterinária) - Escola Superior de Veterinária, Hannover. 
KNEISSL, S. Tiefgefrierkonservierung von pferdesperma: einfluuss der samen-entnahmetechnik, zentrifugation, konfektionerungsform und einfriermethode auf die motilitaet und membranintegritaet der samenzellen. 1993. Tese (Doutorado em Medicina Veterinária) - Escola Superior de Veterinária, Hannover.

LAGARES, M. A.; MEIRELES, L. S.; WALD, V. B.; GREGORY, R. M.; MATTOS, R. C. Efeito de diferentes diluidores sobre a membrana plasmática do espermatozóide eqüino e fertilidade do sêmen resfriado. Revista Brasileira de Ciências Veterinárias, Niterói, v. 7, n. 3, p. 153-156, 2000.

LAGARES, M. A.; PETZOLDT, R.; SIEME, H.; KLUG, E. Preservação do sêmen fresco equino: avaliação da integridade da membrana espermática sob condições hiposmoticas. Arquivos da Faculdade de Veterinária da UFRGS, Porto Alegre, v. 26, n. 1, p. 29-42, 1998.

LOPES, G. F.; LEHUGEUR, C. M.; DREYER, C. T.; RIBEIRO, L. A. O. Efeito da aplicação de Catosal $\mathrm{B} 12^{\circledR}$ no início do encarneiramento sobre a eficiência reprodutiva de ovelhas mantidas a campo no Rio Grande do Sul/Brasil. A Hora Veterinária, Porto Alegre, v. 30, n. 178, p. 13-17, 2010.

MALSCHITZKY, E.; SCHILELA A.; MEIRELLES, L. S.; MATTOS, A. L. G.; GREGORY, R. M.; MATTOS R. C. Artificial photoperiod in pregnant mares and its effect on pregnancy length and postpartum reproductive performance. Pferdeheilkunde, Baden-Baden, v. 17, n. 6, p. 565-569, 2001.

MATTOS, R.C.; CAVALHEIRO, E.P.; GREGORY, R.M.; MIES FILHO, A. Cerovsky - método alternativo, rápido e durável na avaliação morfológica de espermatozoides equinos. Revista Brasileira de Reprodução Animal, Belo Horizonte, v. 14, n. 4, p. 167-172, 1990.

MEIRELlES, L. S.; NEVES, A. P.; VIEIRA, M. J.; KELlER, A.; HÖTT, A. K.; MORAES, I. M. A.; GARBADE, P.; GREGORY, R. M.; MATTOS, R. C. Uso do leite em pó desnatado não inativado e do leite desnatado UHT na preservação e fertilidade do sêmen eqüino resfriado. Ciência Rural, Santa Maria, v. 28, n. 3, p. $467-470,1998$.
MARBACH, W. Alkalische phosphatase (AP) und aspartataminotransferase (AST) des blutplasmas als parameter der kondition von rennpferden und die wirkung von coforta/catosal auf diese enzyme. Pferd Veterinär Medizinische Nachrichten, v. 12, n. 1, p. 63-69, 1980.

Hämatologische parameter zur kondition von rennpferden und die wirkung von Coforta/Catosal auf das erschöpfte. Pferd Veterinär Medizinische Nachrichten, v. 1, n. 1, p. 82-92, 1978.

PEREIRA, R. A.; FARIAS, L. B.; THEOBALD, F.; BRAUNDER, C. C.; LIMA, M. E.; CORRÊA, M. N. Metafilaxia com Catosal B $12^{\circledR}$ para incrementar o ganho de peso de bezerros durante o início da recria. A Hora Veterinária, Porto Alegre, v. 32, n. 188, p. 23-26, 2012.

ROLLIN, E.; BERGHAUS, R. D.; RAPNICKI, P.; GODDEN, S. M.; OVERTON, M. W. The effect of injectable butaphosphan and cyanocobalamin on postpartum serum $\beta$-hydroxybutyrate, calcium, and phosphorus concentrations in dairy cattle. Journal of Dairy Science, Champaign, v. 93, n. 3, p. 978-987, 2010.

SAMPER, J. C. Artificial Insemination. In: SAMPER, J. C. (Ed.). Equine breeding management and artificial insemination. Philadephia: W. B. Saunders, 2000. p. 109131.

SCHMID, E. T.; ESKENAZI, B.; MARCHETTI, F.; YOUNG, S.; WELDON, R. H.; BAUMGARTNER, A.; ANDERSON, D.; WYROBEK, A. J. Micronutrients intake is associated with improved sperm DNA quality in older men. Fertility and Sterility, New York, v. 98, n. 5, p. 1130-1137, 2012.

SHARP, A. A.; WITTS, L. J. Seminal vitamin $\mathrm{B}_{12}$ and sterility. Lancet, London, v. 280, n. 7259, p. 779-780, 1962.

SOLOMON, L. R. Disorders of cobalamin (Vitamin B12) metabolism: emerging concepts in pathophysiology, diagnosis and treatment. Blood Reviews, London, v. 21, n. 3, p. 113-130, 2007.

WATSON, A. A. Seminal vitamin $\mathrm{B}_{12}$ and sterility. Lancet, London, v. 280, n. 7257, p. 644, 1962.

WONG, W. Y.; MERKUS, H. M.; THOMAS, C. M.; MENKVELD, R.; ZIELHUIS, G. A.; STEEGERSTHEUNISSEN, R. P. Effects of folic acid and zinc sulfate on male factor subfertility: a double-blind, randomized, placebo-controlled trial. Fertility and Sterility, New York, v. 77, n. 3, p. 491-497, 2002. 